Галаур, Світлана. «Регулятивна організація топонімів у сучасному українському художньому тексті». Лінгвостилістичні студї, вип. 10, 2019, с. 18-28.

Halaur, Svitlana. "Toponym Regulatory Structure in the Contemporary Ukrainian Fiction Text”. Linguostylistic Studies, iss. 10, 2019, pp. 18-28.

Удк 81'42-028.61

https://doi.org/10.29038/2413-0923-2019-10-18-28

\title{
РЕГУЛЯТИВНА ОРГАНІЗАЦІЯ ТОПОНІМІВ У СУЧАСНОМУ УКРАЇНСЬКОМУ ХУДОЖНЬОМУ ТЕКСТІ
}

\author{
Світлана Галаур \\ Полтавський національний педагогічний університет імені В. Г. Короленка, \\ Полтава, Україна
}

У статті проаналізовано функціювання топонімів у сучасній українській художній прозі та встановлено їхню участь в оформленні текстової категорії регулятивності, яка контролює адекватне сприйняття художньої інформації. 3'ясовано, що регулятивність топонімів залежить від макро- чи мікропозиціювання їх у текстовому просторі, формування на їхній основі мережі стилістичних прийомів, спеціального впорядкування топонімних сигналів регулятивними способами повтором, конвергенцією, винесенням топоназви в сильну позицію, контрастуванням, мовною грою.

Ключові слова: топонім, категорія регулятивності тексту, регулятивна функція, регулятема, спосіб регулятивності.

Halaur Svitlana. Toponym Regulatory Structure in the Contemporary Ukrainian Fiction Text. Thearticle analyzes toponyms functioning in modern Ukrainian prose and specifies their role in determining the text category of regulatoriness, which determines an adequate perception of literary information.

The study has revealed that modern fiction manifests an abundant toponym system. Depending on the context, they show their macro-meso-micro level features. The toponyms are classified according to their paradigmatic, historical, functional, stylistic or referential characteristics.

First of all, toponyms in a text actualize their toponymic meaning, structuring a text space. However, they represent their nominative semantics only occasionally. In the majority of cases, they generate pragmatic information, in other words, perform their regulatory function.

It is proved that toponym regulativity can be characterized by three positions. Firstly, it depends on their macro- or micro positioning in a text area. Macrotoponyms become ideological-conceptual elements which gain a dominant role in the implementation of the author's intention, while microtoponyms function in the text as symbols. Secondly, toponyms are an integral part of the stylistic devices formationsystem, which act as regulatory signals in a text. Among the most common devicesare metaphors, epithets, comparisons, paraphrase, paradoxes, pun. Metonymy demonstrates a peculiar regulatory function. It creates a great panorama of views and social attitudes of the community inhabiting the area and designated by a toponym. Thirdly, a writer uses special regulatory streamlining of toponymic regulatemes -

(C) Галаур С., Східноєвропейський національний університет імені Лесі Українки, 2019.

Це стаття відкритого доступу на умовах CC BY-NC 4.0 
regulativity ways. The latter comprise refrain, convergence, putting a toponym into a stressed position (in a headline mainly), contrasting and puns.

Key words: toponym, text regulativity category, regulatory function, rehulyatema, regulatory way.

Вступ. У царині літературно-художньої топоніміки - i світової, i української - напрацьовано вже чимало. Створено ґрунтовну теоретичну базу (К. Ірісханова, І. Марунич, В. Михайлов, В. Суперанська, О. Фонякова та ін.), досліджено функціювання топонімів у творах багатьох українських письменників - В. Винниченка, Б. Грінченка, О. Кобилянської, В. Кожелянка, Л. Костенко, Д. Павличка, М. Хвильового та ін. (Е. Боєва, В. Калинкін, Ю. Карпенко, Т. Крупеньова, В. Кухаренко, Г. Лукаш, М. Максимюк, О. Мороз, О. Тєлєжкіна, О.Усова та ін.) та визнано, що «не існує більш вдячного мовного матеріалу для художньо-стилістичного використання, ніж власні назви» (Карпенко 61). Справді, топоніми постають особливими прикметами ідіостилю автора, вибудуваної ним унікальної мовної картини, потужними сигналами його інтенції. Твердження про те, що вони $€$ «місткими й ефективними акцентами контексту», «створюють контрасти і світлотінь, підсилюють і приглушують основну тему контексту», вимальовують «основні контури оповіді, зовнішній і внутрішні асоціативні ефекти та діють у чітко заданому автором ключі» (Немировская 114), $є$ незаперечним. Справедливим є і номінування пропріальної лексики, зокрема топонімів, «мовноестетичним меседжем для сприйняття й розуміння тексту адресатом» (Горбач 48), «домінантою інформаційного простору» (Вінтонів 16). Тож вивчення цих мовних одиниць із погляду текстової категорії регулятивності, яка контролює адекватне сприйняття художньої інформації, на часі.

Мета дослідження - установити різновиди топонімів, які функціюють у сучасній художній прозі, та з'ясувати текстові умови активізації їхньої регулятивної функції.

Матеріал і методи дослідження. Матеріалом розвідки слугували топоніми в художніх прозових текстах кінця XX - початку XXI століть. Дослідження грунтоване на сучасних методах аналізу художнього тексту як форми комунікації та явища ідіостилю - лінгвопоетичній інтерпретації, що передбачає тлумачення змісту тексту на тлі мовних одиниць та їхніх системно-семантичних відношень, інформаційно-змістовому методі, спрямованому на аналіз змістового розгортання тексту, регулятивному структуруванні, зорієнтованому на виявлення регулятем - стимуляторів різних інформаційно-комунікативних ефектів. Конкретно-практичним методом став описовий із застосуванням прийомів спостереження, порівняння, класифікацї.

Результати дослідження та дискусія. Сучасна українська художня проза маніфестує розлогу за обсягом та позначуваним географічним 
обширом систему топонімів. Зактивізовані хороніми (назви територій горизонтального членування), ойконіми (назви населених пунктів), ороніми (назви елементів рельєфу земної поверхні), гідроніми (назви водних об'єктів): <...> насправді, якби не обвалились у вісімдесяті ціни на нафтту та не почалися розборки в Політбюро, ми б із тобою й досі в СРСР жили (Забужко); Оце я під'їжджав до вашого села і замилувався назвою «Демидівка» («Ільківці», «Петрова балка», «Цибулівка»). Яка гарна назва! (Гримич); Одного разу на відпочинку в Карпатах, у Гребенові, побачила на березі річки Зелем'янки закинуту напівзруйновану будівлю (Вдовиченко, Пів'яблука); Я би назвав цей острів Захащений Негнучкими Людьми та Гнучкими Вербами (Денисенко); На одному знімку краєчок університетського фронтону за його спиною переконливо свідчив, що це парк Костюшка, віддавна вже парк Франка, але львів'яни вперто називають його по-старому (Вдовиченко, Бора); Наступного ранку Іветта навмання спрямувала «шкоду» на Житомирську трасу (Дашвар, Мати все); Дружина з батьками виїхали в Угорщину, в село над Балатоном (Винничук). Хоронімна лексика репрезентована територіонімами (адміністратонімами, 3-поміж яких сувереноніми - назви держав, райононіми - назви адміністративних частин країни, області, штату, округу, краю тощо, та натуралонімами, з-поміж яких континентоніми назви континентів, регіононіми - назви територіальних одиниць, що вирізняються 3-поміж інших специфічними рисами); гідротериторіонімами (інсулонімами - назвами островів, пенінсулонімами - назвами півостровів, пляжонімами - назвами пляжів); віонімами - назвами шляхів сполучення. Групу ойконімів формують астіоніми (назви поселень міського типу) та комоніми (назви поселень сільського типу). На помежів'ї хоронімів та ойконімів можна розглядати годоніми - назви лінійних об'єктів у населеному пункті, агороніми - назви площеподібних об'єктів, дендроніми - назви парків, кварталоніми - назви кварталів, некроніми - назви місць поховання тощо. Ойконімію врізноманітнюють також найменування споруд, що асоціюють з тим чи тим населеним пунктом, - домоніми, 3поміж яких функційно активними $\epsilon$ еклезіоніми - назви культових будівель. Сегментами оронімії̈ $\epsilon$ едитоніми - назви гірських систем, скопулусоніми - назви гірських вершин, монтісоніми - назви полонин тощо. Гідроніми містять підкласи океанонімів - назв океанів, пелагонімів назв морів, потамонімів - назв річок, лімнонімів - назв озер тощо.

Усі топоніми в тексті виявляють свій макро-, мезо- чи мікрорівневий характер. До макротопонімів належать власні назви великих фізикогеографічних об'єктів, що мають широку сферу вживання, загальновідомі. Зазвичай це найменування континентів, державних об'єднань, держав, великих територій усередині держави та на покордонні кількох держав. Групу мікротопонімів формують здебільшого ті, які окреслюють сферу ойкохоротопонімії. Мезотопонімія охоплена зазвичай ойко-, оро- чи гідронімами. Водночас межа макро-/мезо-/мікротопонімного простору в 
художніх творах достатньо гнучка, оскільки навіть один і той самий топонім можна додати до будь-якої просторової групи відповідно до контексту. Усі макро-, мезо- чи мікротопоніми окремо взятого твору перебувають у тісних синтагматичних і парадигматичних зв'язках на тлі виформовуваного ними топонімного обширу, у якому одні компоненти слугують для реципієнта певним досвідом для сприйняття й розуміння інших компонентів.

У сучасному художньому тексті топоніми характеризують не лише за парадигмальними ознаками. Їх осмислюють також за походженням (реальні, ірреальні, закодовані), історичним критерієм (сучасні, архаїчні), функційним навантаженням (переднього й заднього плану), стилістичною роллю (нейтральні та стилістично забарвлені). Так, у романі Ю. Андруховича «Рекреації» всі події відбуваються в загадковому місті Чортополі. Цей астіонім $\epsilon$ ірреальним, переднього плану, стилістично забарвленим. Його внутрішня форма підказує, що описуване місце пов'язане 3 містикою. У тексті використана низка ірреальних заднього плану нейтральних i стилістично забарвлених годонімів, агоронімів, гідронімів, скопулусонімів, комонімів, за основу творення яких, залежно від мети уведення в текст, узято меморіальну, асоціативну, квалітативну мотивації: вул. Дзержинського, вул. Івана Хрестителя, вул. Понятовського, вул. Сакраменток, вул. Тиха, площа Воскресіння, площа Ринок, Річка, Писана Скала, Сільще, Красностав. Крім того, у тексті функціюють реальні сучасні й архаїчні, заднього плану, нейтральні та стилістично забарвлені топоніми: Київ, Львів, Шепетівка, Зальцбург, Відень, Женева, Люцерн, Москва, Ленінград, Брюссель, Варшава, Валенса, Караганда, Фергана. Вони, переконує В. Серебрякова, демонструють «два різноспрямовані процеси - надання топонімної реалістичності та поетизацію реальних топонімів» (99).

Топоніми як компоненти художнього тексту передовсім маніфестують своє топонімне значення, структуруючи простір, умовно окреслюючи «контурну мапу, на яку потім накладається дія» (Хрептулов 167). Крім того, топоніми надають текстові історичної конкретики та вказують на час дії. Отже, основними їхніми функціями $є$ просторово-орієнтаційна, хронотопна та локалізаційна. Усі вони репрезентовані в межах загальнішої функції - номінативної (констатувального чи диференційного характеру). Водночас топонім, стверджує Ю. Карпенко, з огляду на виокремлення у своїй семантиці інших двох сегментів - «етимологійного (з оголеною внутрішньою формою)» та стилістичного «звучання» (17-20), - «містить незмірний, величезний обсяг інформації» (61), яка імпліцитна в мові, але в художньому тексті «виявляється експліцитно - відповідно до настанов автора, його задуму» (Мороз 352). «Система власних назв у мові $\epsilon$ первинною, - розвиває цю думку далі В. Калинкін, - а літературні номени утворюють вторинну семіотичну систему, яка моделює первинну» (82). Експліцитність топонімів, про яку йдеться, а також генерування їхньої інформаційно-прагматичної функції, що підпорядковує собі естетичну, 
соціально-історичну, культурологічну, забезпечує особлива регулятивна організація цих одиниць, яку загалом можна схарактеризувати за трьома позиціями.

По-перше, високу інформаційну наснагу мають топоніми макрорівневого характеру. Вони зазвичай стають ідейно-концептуальними елементами, яким належить домінантна роль у реалізації авторського задуму. Так, у новелі Б. Мельничука «Брудно ви живете...» з участю сувереноніма Італія порушено проблему спотвореного світосприйняття українців, які шукають долі на чужині: Он дивися, сонце вже до обрію котиться, а після ранкового дощу на вулищю годі вийти, потонеш у болоті. <...> Без гумаків хоч із хати не виходь. Не те, що в Італії; Вибачте мені, Стефаніє Андріївно, за дочку, вона після Iталії - як сама не своя. Не менш важливими в художніх текстах виявляються й мікротопоніми. Реалізуючись у тексті, на перший погляд, номінативно, вони здатні функціювати як символи, що $є$ очевидним, наприклад, у романі Люко Дашвар «Мати все». Уживаний у ньому кварталонім Троєщина актуалізує сему «кримінальний район», тому не дивно, що юнакові з Троєщини важко сформувати позитивну думку про себе, побороти стереотипне уявлення киян про таких, як він: Cmac хотів зрозуміти: на скільки зустрічей із звичайним хлопцем із троєщини стане шляхетної панянки; I - чао, Троєщина! Проте у ньому вже тепер не розпізнати традиційно осміяного «хлопця з Троєщини» (Дашвар, Мати все).

По-друге, регулятивність топонімів вибудовує особлива їхня синтагматика. «Лексичне оточення, - переконана М. Максимюк, - здатне актуалізувати різноманітні потенційні семи, що $є$ у топоніма, підсилити його експресивність i емоційну виразність» (98). Взаємодіючи 3 контекстом, топоніми зазвичай розгортаються в різні стилістичні прийоми, які виявляють конотативні значення, провокують мовноестетичні переосмислення, продукують безмежні можливості свого інформаційного наповнення, отже, постають регулятемами. Регулятивність топонімів зреалізовується в метафорі: Вирує Андріївський узвіз (Найдич), порівнянні: <..>[Данута] уявляла, як на мить бризнуть різнобарвними іскрами його серйозно-насмішкуваті очі, як делікатною рукою він почухає свої волохаті груди, з гідністю, немов президент Сполучених Штатів Америки, підніме слухавку телефона, $i$ вони розмовлятимуть (Медвідь), перифразі: На цьому ж боці - «царство щасливої старості» [Хорватія. - С. Г.]. Здебільшого тут відпочивають жваві пенсіонери (Роздобудько), парадоксі: Тож нехай наша велика ріка Дніпро вливається у велику ріку Лімпопо (Даниленко), ампліфікації: У неїщасливий шлюб. Гарна робота. Львів. І власна квартира неподалік площі Ринок та каплиці Боїмів, де на даху Скорботний Ісус питає перехожих, чи їхнє страждання є більшим, ніж його. Та Злата переконана - це не до неї (Гранецька), каламбурі: Яка шана селу, така й Шанівка (Дашвар, Село не люди). Особливу регулятивну роль відіграє метонімія, яка увиразнює яскраву панораму думок, настроїв спільноти, що населяє місцевість, 
позначувану топонімом: <...> щедра на платні обійми, знаменита куртизанка Європа вміло користувалась розтринькувачкою власних чеснот і багатств - країною УКР, - бо добре знала: якщо мати під боком таких сусідів, як безголові укри, тоді не обов'язково годувати своє військо чи армію своїх робітників (Матіос); Посол сказав лише одну фразу. Але яку! «Албанія спокійно залишилась осторонь Об'єднаної Європи, перебуваючи у самому її центрі (Курков).

По-третє, топоніми можуть мати регулятивне оформлення з огляду на спеціальну акцентуацію в тексті, яка досягається різними регулятивними способами - повтором, конвергенцією, винесенням топоназви в сильну позицію (найчастіше в заголовок), контрастуванням, мовною грою.

Повтор топонімів, безперечно, породжує додаткову текстову інформацію. Мікроповтор сувереноніма Україна в романі Люко Дашвар «Село не люди» допомагає, зосібна, наголосити на традиційному прикладанні до пляшки як помилковому розумінні гостинності: «Де ви таке в Україні бачили, щоб гості у хату, а хазяї пляшку не виставили? От ви Україну досліджуєте - то скажіть: є в Україні таке місце, де від гостей пляшки ховають?». Дублювання комоніма Курилівці замість усіх найменувань міст у країні Гюлістан (назва ірреальна, закодована, позначає Україну) експлікує тему домінувальної ролі села в розвиткові держави та критичного стану урбанізації (Даниленко). Висока частотність топонімних номінацій збільшує ймовірність вибудовування наскрізного топонімного образу, персонажа-топоніма, крізь призму прецедентності якого читач сприймає всі текстові події. Наприклад, уведення в текст повноцінного головного героя - міста Львова - способом нагромадження в межах його макропростору мікроойкохоронімів спостережено в багатьох сучасних українських художніх творах. Як зауважив А. Кокотюха, «древнє, оповите легендами та прикметне середньовічними мурами королівське місто не просто має безліч власних легенд, а й здатне народжувати нові. Причому всякій романтичній загадковій історії, що відбувається в декораціях міста Лева, віриш швидше, ніж якби ця штука сталася деінде за його межами» (Бут 7), тож регулятивність повтору таких топонімів безапеляційна.

Нерідко топоніми, дублюючись у складі різних стилістичних прийомів, зазнають варіантних експлікацій. У цьому разі зафіксовано регулятивну організацію топонімів не так способом повтору, як конвергенції. Наприклад, у романі В.Кожелянка «Дефіляда в Москві» стилістично нейтральний макротопонім переднього плану Україна утворює такий варіаційний ряд: Радянська Україна, Ненька-Україна, Українська Держава, Українська Батьківщина, Українська Вітчизна, УССР (Українська Совєтська Соціалістична Республіка), Велика Україна, Велика Українська Імперія, Імперія Трьох Морів, СШУ (Сполучені Штати України), Українське Царство, Київська Русь, Хохляндія. Лише до деяких із цих варіантних найменувань застосований повтор, що допомагає уникнути тавтології, урізноманітнити розповідь і, зрозуміло, наповнити зміст 
додатковими прагматичними ефектами. Більшість же із них, структурованих конвергентно, виконує потужну регулятивну функцію підкреслює хронотопічний зміст, проливає світло на фантастичні футурологічні проекти щодо майбутнього України, фіксує культурологічну інформацію.

Топоніми в заголовках художніх творів постають інформаційними центрами. Наприклад, Іловайськ в однойменному романі Є.Положія сприймається не лише як прецедентна назва трагедії українського народу, а і як простір зіткнення двох цивілізацій - української та російської. Назва роману С. Андрухович «Фелікс Австрія» апелює до девізу АвстроУгорщини: «Bellagerantalii, tu felix Austria, nube» (Нехай воюють інші, а ти, щаслива Австріє, укладай шлюби), у контексті якого і прочитують неспішну динаміку роману, усвідомлюють відчуття радості й спокою осторонь від шаленого ритму життя, любов до людей, до самого себе.

Контрастування із застосуванням топонімів $\epsilon$ ефективним регулятивним способом, який уможливлює висвітлення ідейнотематичного навантаження твору за умови значної економії мовних ресурсів. Поширеним у сучасній українській художній прозі $є$ лексикоакцентуаційне контрастування, в основу якого покладено несумісність стилів мовлення: - Ми ноу Америка! - забелькотів Пришебей. - Ми $з$ Юкрейн. - Де чей довбаний Юкрейн? - O, єс, - ляснув себе по лобі коротун. Юкрейн - це ж у Мавританії; Скажітє, мілєйшій, как пройті на улицу Міра? Тут немає такої вулиці, - неприязно відповів пузань. - Ну как там она у вас називаєца? - Степана Бандери. - Так как пройті на уліцу Бєндєри? Москалям нема що робити на вулищі Степана Бандери, - відповів той. Шо ви, я совсем не тот, за кого ві меня принимаєтє. Я с Дебальцево (Даниленко). Популяризується і графіко-акцентуаційне контрастування. Зокрема, топонімні назви, що позначають географічне місце, розташоване за межами державно-мовного простору автора, часто трансльовані іншомовною графікою: На виїзді з Моsсаи ми поминули «капе», і я подумав, що по дорозі назад саме тут можуть виникнути найбільші проблеми (Шкляр). Топоніми такого формату виконують функцію документалізації, коли «письменник домагається більш точної, “документальної” презентації реалї̈», «даючи змогу читачеві долучитися до описуваної дійсності». У цьому разі, наголошує С. Мельник, «позначуване місце стає в тексті не просто предметом опису, а важливим “елементом декорацій” для описуваних подій і сцен» (178).

Дедалі більшого поширення набуває мовна гра з топонімами. Мовні девіації в тексті збуджують уяву читача, змушують його мозок активно працювати «услід за автором». Обстеження сучасних українських художніх текстів ілюструє такі найтрадиційніші авторські експерименти 3 топонімними одиницями: уживання географічних назв у формі множини, написання їх із малої літери: Гідроакустик був фанатом зйомки на кінокамеру, знімав усі закордонні практики на навчальних суднах, усі ті 
Лас-Пальмаси, Буенос-Айреси й Гібралтари (Санченко); Редька по ній [шенгенській візі] тільки разочок з'їздила на фестиваль із Мериліном Менсоном як хедлайнером до Німеччини, та ще покаталася по польщахугорщинах під шумок, теж на вселенські собори волоцюг у наметах під звєрську музичку на кількох сценах (Карпа, Піца); додавання до топоніма суфіксів, які інкорпорують позитивну (меліоративну, демінутивну, звеличувальну) чи негативну (пейоративну, аугментативну, принизливу, насмішкувату) конотації: Квиточок від Берлінчика до Lörraшка, куплений у провіднички, потряс мене цінушкою в 111 (!) євриків, які довелося відвалити з власної кишені (Андрухович, Дереш, і Жадан); творення оказіонального топоніма на основі реального: Так і почалась моя Одіссея. «У пошуках шоколадноголового пупсика». Через усю Україну до Німеччини. Рава Пупська, Пупсемишль, Пупсезден (Карпа, 3 роси); трансформація фразеологізмів з уведенням до їхнього складу топонімів: <..> іще волинською Мавкою - незбагненною Лесею - сказано, як у стоячу воду Шацьких озер глянуто: сутужна, сину мій, укрівська справа (Матіос) тощо.

Висновки та перспективи досліджень. Складну й розгалужену систему літературно-художніх топонімів можна описати за парадигмальними, історичними, функційними, стилістичними, референційними параметрами. У сучасній художній прозі топоніми виконують номінативну функцію лише зрідка, частіше вони сприяють точнішому та виразнішому висвітленню художнього задуму, тобто беруть участь в оформленні текстової категорії регулятивності. Регулятивність топонімів залежить від макро- чи мікропозиціювання їх у текстовому просторі, формування на їхній основі мережі стилістичних прийомів, спеціального регулятивного впорядкування топонімних сигналів. Очевидним $\epsilon$ те, що запропонована розвідка порушує проблему типології інформації, породжуваної в художньому тексті як топонімами зосібна, так і різними власними назвами загалом, тож перспективність майбутніх студій у цьому напрямкові беззаперечна.

\section{Список використаних джерел}

Андрухович, Софія. Фелікс Австрія. Львів : Видавництво Старого Лева, 2015.

Андрухович, Юрій, Дереш, Любко, і Жадан, Сергій. Трициліндровий двигун любові. Харків : Фоліо, 2008.

Андрухович, Юрій. Рекреації. Харків : Фабула, 2017.

Винничук, Юрій. Цензор снів. Київ : Довженко Букс, 2016.

Вдовиченко, Галина. Бора. Харків : Книжковий клуб «Клуб сімейного дозвілля», 2011.

Вдовиченко, Галина. Пів'яблука. Інші пів'яблука. Львів : Видавництво Старого Лева, 2019.

Гранецька, Вікторія. Абонентська скринька. Львів. Кава. Любов. Харків : Книжковий клуб «Клуб сімейного дозвілля», 2015.

Гримич, Марина. Варфоломієва ніч. Львів : Кальварія, 2002.

Даниленко, Володимир. Газелі бідного Ремзі: Любовні послання мудрого й правовірного кримського хана Хаджи Селіма Герая I своїм сорока жінкам із країни гяурів. Львів : ЛА «Піраміда», 2008.

Дашвар, Люко. Мати все. Харків : Книжковий клуб «Клуб сімейного дозвілля», 2011. 
Дашвар, Люко. Село не люди. Харків : Книжковий клуб «Клуб сімейного дозвілля», 2014. Денисенко, Лариса. Сарабанда банди Сари. Київ : Нора-Друк, 2014.

Забужко, Оксана. Музей покинутих секретів. Київ : Факт, 2009.

Карпа, Ірена. 3 роси, з води і з калабані. Харків: Книжковий клуб «Клуб сімейного дозвілля», 2012.

Карпа, Ірена. Піца «Гімалаї». Харків : Книжковий клуб «Клуб сімейного дозвілля», 2013.

Кожелянко, Василь. Дефіляда в Москві. Львів : Кальварія, 2000.

Курков, Андрій. Остання любов президента. Харків : Фоліо, 2019.

Матіос, Марія. Мicmер і місіс Ю в краӥні укрів. Mr. \& Ms. U in country UA. Львів: Літературна агенція «Піраміда», 2006.

Медвідь, Ганна. «Велосипед». Медвідь, Ганна. На струнах душі. Львів : ЛА «Піраміда», 2014 , с. 196-201.

Мельничук, Богдан. «Брудно ви живете». Літературна Україна, 8 вересня 2016, (№ 34), c. 12.

Найдич, Ніна. «Таємниця маленького міста». Найдич, Ніна. Казки та історії для дорослих, які були дітьми. Київ : Гамазин, 2016, с. 169-172.

Положій, Євген. Іловайськ: розповіді про справжніх людей. Харків : Фоліо, 2015.

Роздобудько, Ірен. Мандрівки без сенсу і моралі. Київ : Нора-Друк, 2011.

Санченко, Антон. Нариси бурси. Київ : Темпора, 2011.

Шкляр, Василь. Елементал. Харків : Книжковий клуб «Клуб сімейного дозвілля», 2014.

\section{Sources}

Andrukhovych, Sofiia. Feliks Avstriia. Lviv : Vydavnytstvo Staroho Leva, 2015.

Andrukhovych, Yurii, Deresh, Liubko, and Zhadan, Serhii. Trytsylindrovyi dvyhun liubovi. Kharkiv : Folio, 2008.

Andrukhovych, Yurii. Rekreatsii. Kharkiv : Fabula, 2017.

Vynnychuk, Yurii. Tsenzor sniv. Kyiv : Dovzhenko Buks, 2016.

Vdovychenko, Halyna. Bora. Kharkiv : Knyzhkovyi klub "Klub simeinoho dozvillia", 2011.

Vdovychenko, Halyna. Piviabluka. Inshi piviabluka. Lviv : Vydavnytstvo Staroho Leva, 2019.

Hranetska, Viktoriia. Abonentska skrynka. Lviv. Kava. Liubov. Kharkiv : Knyzhkovyi klub "Klub simeinoho dozvillia", 2015.

Hrymych, Maryna. Varfolomiieva nich. Lviv : Kalvariia, 2002.

Danylenko, Volodymyr. Hazeli bidnoho Remzi: Liubovni poslannia mudroho y pravovirnoho krymskoho khana Khadzhy Selima Heraia I svoim soroka zhinkam iz krainy hiauriv. Lviv : LA "Piramida", 2008.

Dashvar, Liuko. Maty vse. Kharkiv : Knyzhkovyi klub "Klub simeinoho dozvillia”, 2011.

Dashvar, Liuko. Selo ne liudy. Kharkiv : Knyzhkovyi klub "Klub simeinoho dozvillia”, 2014.

Denysenko, Larysa. The Sarabande of Sara's Band. Kyiv : Nora-Druk, 2014.

Zabuzhko, Oksana. Muzei pokynutykh sekretiv. Kyiv : Fakt, 2009.

Karpa, Irena. Z rosy, z vody i z kalabani. Kharkiv : Knyzhkovyi klub "Klub simeinoho dozvillia", 2012.

Karpa, Irena. Pitsa "Himalai”. Kharkiv : Knyzhkovyi klub "Klub simeinoho dozvillia”, 2013.

Kozhelianko, Vasyl. Defiliada v Moskvi. Lviv : Kalvariia, 2000.

Kurkov, Andrii. Ostannia liubov prezydenta. Kharkiv: Folio, 2019.

Matios, Mariia. Mister i misis Yu v kraini ukriv. Mr. \& Ms. U in country UA. Lviv : LA "Piramida", 2006.

Medvid, Hanna. "Velosyped". Medvid, Hanna. Na strunakh dushi. Lviv : LA "Piramida”, 2014, pp. 196-201.

Melnychuk, Bohdan. "Brudno vy zhyvete”. Literaturna Ukraina, 8 veresnia 2016, (no 34), p. 12.

Naidych, Nina. "Taiemnytsia malenkoho mista". Naidych, Nina. Kazky ta istorii dlia doroslykh, yaki buly ditmy. Kyiv : Hamazyn, 2016, pp. 169-172. 
Polozhii, Yevhen. Ilovaisk: rozpovidi pro spravzhnikh liudei. Kharkiv : Folio, 2015.

Rozdobudko, Iren. Mandrivky bez sensu i morali. Kyiv : Nora-Druk, 2011.

Sanchenko, Anton. Narysy bursy. Kyiv : Tempora, 2011.

Shkliar, Vasyl. Elemental. Kharkiv : Knyzhkovyi klub "Klub simeinoho dozvillia”, 2014.

\section{Список використаної літератури}

Бут, Сергій. Листи з того світу. Харків: Книжковий клуб «Клуб сімейного дозвілля», 2015.

Вінтонів, Тетяна. Реальна онімія як засіб образності в історичній оповіді. Дис. ...канд. філол. наук: 10.02.15. Донецьк, 2008.

Горбач, Олена. Ономастикон українських сатирично-гумористичних текстів кіния XX початку XXI століття. Дис. ...канд. філол. наук: 10.02.01. Кам'янецьПодільський, 2017.

Калинкин, Валерий. «От литературной ономастики к поэтонимологии». Логос ономастики, № 1, 2006, с. 81-9.

Карпенко, Юрій. Літературна ономастика. Одеса: Астропринт, 2008.

Максимюк, Марта. «Особливості функціонування топонімів у романі В.Кожелянка „Дефіляда в Москві”». Логос ономастики, №1, 2006, с. 97-103.

Мельник, Світлана. «Прагматичні функції іншомовних вкраплень в українській прозі кінця XX - початку XXI століть». Наукові записки Національного університету «Острозька академія». Серія «Філологічна», вип. 52, 2015, с. 177-9.

Мороз, Оксана. «Топоніми як компоненти художнього тексту (на матеріалі роману «Сонячна машина» В. Винниченка)». Сучасні проблеми мовознавства та літературознавства, вип. 15, 2011, с. 351-5.

Немировская, Т. В. «Некоторые проблемы литературной ономастики». Актуальные вопросы русской ономастики. Киев : УМКВО, 1988, с. 112-22.

Серебрякова, Валерія. Концептуалізація поетонімосфери циклу романів С. Мейер «Сутінки». Дис. ...канд. філол. наук: 10.02.04. Одеса, 2016.

Хрептулов, А. А. «Топонимическая стратификация художественного произведения». Шоста Республіканська ономастична конференція. Т. 1. Теоретична та історична ономастика. Літературна ономастика. Одеса, 1990, с. 167-8.

\section{References}

But, Serhii. Lysty z toho svitu. Kharkiv: Knyzhkovyi klub "Klub simeinoho dozvillia”, 2015.

Vintoniv, Tetiana. Realna onimiia yak zasib obraznosti $v$ istorychnii opovidi. PhD dissertation. Donetsk, 2008.

Gorbach, Olena. Onomasticon of Ukrainian satirical and humorous texts of the late XX - early XXI century. PhD dissertation. Kamianets-Podilskyi, 2017.

Kalinkin, Valerij. “Ot literaturnoj onomastiki k pojetonimologii”. Lohos onomastyky, no 1, 2006, pp. 81-9.

Karpenko, Yurii. Literaturna onomastyka. Odesa : Astroprynt, 2008.

Maksymyuk, Marta. "Peculiarities of Functioning of Toponyms in V. Kozhelyanko's Novel “Defiliada v Moskvi” [Booze In Moscow]”. Lohos onomastyky, no 1, 2006, pp. 97-103.

Melnyk, Svitlana. "Prahmatychni funktsii inshomovnykh vkraplen v ukrainskii prozi kintsia XX pochatku XXI stolit”. Scientific Notes of Ostroh Academy National University: Philology Series, iss. 52, 2015, pp. 177-9.

Moroz, Oksana. "Toponimy yak komponenty khudozhnoho tekstu (na materiali romanu «Soniachna mashyna» V. Vynnychenka)". Suchasni problemy movoznavstva ta literaturoznavstva, iss. 15, 2011, pp. 351-5.

Nemirovskaja, T. V. "Nekotorye problemy literaturnoj onomastiki". Aktual'nye voprosy russkoj onomastiki. Kiev: UMKVO, 1988, pp. 112-22. 
Serebriakova, Valeriia. Kontseptualizatsiia poetonimosfery tsyklu romaniv S. Meier "Sutinky". PhD dissertation. Odesa, 2016.

Khreptulov, A. A. "Toponymycheskaia stratyfykatsyia khudozhestvennoho proyzvedenyia". Shosta Respublikanska onomastychna konferentsiia. Vol. 1. Teoretychna ta istorychna onomastyka. Literaturna onomastyka. Odesa, 1990, pp. 167-8.

Стаття надійшла до редколегії 08.02.2019 